\title{
Unequal opportunities and ethnic origin : The labor market outcomes of second-generation immigrants in France
}

\author{
Arnaud Lefranc*
}

August 2009

\begin{abstract}
This paper makes two contributions to the empirical analysis of the socio-economic achievement of ethnic minorities. The first contribution is methodological. I rely on a discussion of the concept of equality of opportunity to analyze how the disadvantage suffered by ethnic minorities should be defined and empirically measured. The second contribution is empirical. I estimate the disadvantage suffered by second-generation immigrants, in the access to education, employment and earnings in France. Contrary to most papers in this area, I identify second-generation immigrants in a consistent way, using information of parental geographic and national origin. I also discuss the extent to which measured earnings differentials reflect ethnic discrimination or ethnicblind social inequalities.
\end{abstract}

${ }^{*}$ Université de Cergy-Pontoise, THEMA and Robert Schuman Center for Advanced Studies, European University Institute. Email: Arnaud.Lefranc@eui.eu.

I thank Virginie Guiraudon and seminar participants at the EUI Migration working group, the INEDCOMPAS workshop and the University of Evry conference on "Measuring discriminations" for useful suggestions. 


\section{Introduction}

In recent years, a growing body of research has investigated the socio-economic success of ethnic minorities in developed countries. Overall this literature suggests that ethnic minorities experience significant and sometimes large disadvantages in educational attainment, access to employment and earnings acquisition. Not surprisingly, the extent of this advantage varies by country and ethnic origin. More disturbing is the fact that the impact of ethnic origin on individual outcomes also varies between studies because different authors use different methodologies to assess it. In some cases, ethnic disadvantage is simply assessed by comparing the mean outcome of ethnic minorities and natives. In others, authors control for the influence of confounding variables such as individual education, age or social origin. While including or not such control variables is likely to influence the empirical assessment of the disadvantage suffered by ethnic minorities, the reasons for doing so (or not) are rarely discussed. This discussion is however of paramount importance for the interpretation of measured ethnic disadvantages. In many applications, this disadvantage is interpreted as a specific ethnic-based discriminatory penalty. However, the lower socio-economic achievement of ethnic minorities can also arise from other forms of social, non-ethnic, penalties. Whether these social penalties should be counted in the measurement of ethnic disadvantage and whether they can, empirically, be disentangled from the effect of ethnic discrimination are of course crucial issues for quantitative analysis.

The first objective of this paper is to examine how ethnic disadvantage should be measured and how the different measures used in empirical work should be interpreted. The analysis developed in this paper is both normative and positive. First, the analysis rests on the discussion of the notion of equality of opportunity. In fact, most empirical assessments of ethnic disadvantage aim at measuring by how much we deviate from a reference situation in which equality of opportunity, in relationship to ethnicity, would prevail. However, as discussed below, equality of opportunity is a slippery notion that conveys a wide variety of conceptions of social justice. And these different conceptions of social justice imply different definitions of what should count as ethnic disadvantage. In the rest of the paper, I discuss the different notions of equality of opportunity that underlie the measures of ethnic disadvantage commonly used in the literature. I also discuss how the different measures of ethnic disadvantage used in the empirical literature can capture different mechanisms responsible for the lower socio-economic achievement of ethnic minorities.

The second objective of this paper is to analyze the ethnic disadvantage suffered by second-generation immigrants in France. Compared to most other European countries, the French population incorporates sizeable ethnic minorities, as a result of large and old migration flows. Nevertheless, empirical evidence on the achievement of these minorities is still relatively recent and remains limited. The reason for focusing on second-generation immigrants is that it is the first generation born and socialized in the host society. Hence there are more reasons to expect that their socio-economic outcomes will come close to the ones of natives, than in the case of first-generation migrants who usually bear the cost of the migration decision 1

While second-generation are crucial for assessing the extent of ethnic assimilation, the French colonial history makes the identification of second-generation immigrants complicated. In available data sets, second-generation migrants are usually identified based on the geographic origin of their parents. However, using this sole piece of information leads

\footnotetext{
${ }^{1} \mathrm{~A}$ second motivation for looking at second and subsequent generations is that it provides a way to assess the extent of assimilation or convergence between the socio-economic outcomes of ethnic minorities and those of natives. This issue will not be investigated in the present paper.
} 
to confuse two ethnically distinct populations : the children of ex-colonists and the children of the autochthonous population of France's former colonies. Most studies pool these two groups, hence leading to a biased assessment of the disadvantage experienced by ethnic minorities. This paper examines the extent of this bias and provides a consistent estimation of ethnic disadvantage in France, relying on a unique representative data set that documents parents' geographic and national origin. Based on this information, I examine the socio-economic achievement of three major groups : second-generation immigrants from North Africa, children of North African ex-colonists (pieds noirs) and second-generation immigrants from Southern Europe.

From an empirical perspective, the second contribution of this paper is to provide an in-depth analysis of the socio-economic outcomes of ethnic minorities and of their determinants. So far, empirical studies have mostly concentrated on the educational attainment and the access to employment of ethnic minorities and their earnings level have remained largely unstudied. In this paper, I provide a comprehensive analysis of the major aspects of labor market outcomes : human capital accumulation, labor force participation, unemployment and earnings. I also discuss the mechanisms responsible for the lower achievement of ethnic minorities. In particular, by carefully taking into consideration individual social origin, I discuss the extent to which measured ethnic disadvantage arise from ethnic discrimination or social inequality.

The rest of the paper is organized as follows. Section 2 discusses, from a methodological perspective, the measurement and interpretation of ethnic disadvantage. Section 3 reviews related empirical studies on France. Section 4 presents the data and estimation procedure used in this paper. Section 5 presents the main results.

\section{Three notions of ethnic disadvantage}

Most analyses of the socio-economic outcomes of ethnic minorities aim at assessing the extent of the disadvantage suffered by these minorities, or, in rarer cases, the advantage that they enjoy. This assessment is motivated from two distinct perspectives. First, from a normative perspective, the disadvantage suffered by ethnic minorities, is often understood as a measure of the deviation from a reference situation in which equality of opportunity would prevail between natives and ethnic minorities. Second, it is sometimes seen, from a positive perspective, as a measure of the extent of ethnic discrimination suffered by these minorities.

The disadvantage suffered by ethnic minorities is usually defined as the difference in achievement between these minorities and a reference group of natives, where achievement can itself be measured by a variety of socio-economic outcomes, including educational and labor market outcomes 2 In the literature, this disadvantage is often referred to as the "ethnic disadvantage" or "ethnic penalty". In practice, there are, however, many ways to empirically define and measure this achievement gap. The objective of this section is to analyze and compare the various notions and measures of disadvantage used in empirical work, to discuss their analytical content and to identify the notion of equality of opportunity that they refer to.

Measures of the ethnic gap mostly differ by their choice of the reference group, among the native population, used in the comparison with ethnic minorities. For instance, Heath and Cheung (forthcoming) and Phalet and Heath (2007) consider two distinct measures of the achievement gap : on the one hand, the difference in mean outcomes between

\footnotetext{
${ }^{2}$ In this section, I will implicitly consider that the achievement gap is defined by the difference in mean achievement between natives and ethnic minorities. This assumption will be discussed and relaxed in section 5
} 
ethnic minorities and natives, which they refer to as the gross ethnic disadvantage; on the other hand, the difference between the outcome of ethnic minorities and that of natives endowed with a similar amount of human capital, which they call the net disadvantage. In the former case, the reference group is the overall native population; in the latter, it is the subgroup of natives who have similar education and experience as the ethnic minority under study. As we will discuss below, other studies have defined the ethnic disadvantage differently by using alternative reference groups of natives, such as individuals with similar social origin or similar cognitive ability.

This diversity of definitions of ethnic disadvantage is, to some extent, confusing and makes comparisons between studies and across countries difficult. Furthermore, the choice of a particular reference group for measuring ethnic disadvantage is most often not discussed. This seems particularly problematic given that this choice may have important consequences for empirical evaluations. In essence, the diversity of measures of ethnic disadvantage mirrors the diversity of views of what the achievement of ethnic minorities should be if they were not subject to any particular disadvantage. To a large extent, it echoes a more general lack of consensus both in political theory and among public conceptions regarding the meaning and interpretation of equality of opportunity. Equality of opportunity is indeed a slippery notion that conveys a wide variety of conceptions of social justice.Identifying the conceptions of social justice that underly the various notions of ethnic disadvantage appears crucial, from a theoretical perspective.

Additionally, the variety of definitions of ethnic disadvantage used in the literature also reflects the multiplicity of social and economic mechanisms that shape ethnic disadvantage. In this respect, different measures of the disadvantage suffered by ethnic minorities may capture different aspects of these social and economic mechanisms. But this calls for an explicit discussion of what aspects of the socio-economic disadvantage of ethnic minorities should be included in the measurement of ethnic penalty. For instance, when assessing ethnic penalties in education, should we count as part of the ethnic disadvantage the fact that ethnic minorities usually come from less socially privileged social origin and, as a result, face lower educational prospects ? Furthermore, from a practical perspective the ability of a given notion disadvantage to capture a specific mechanism of ethnic penalty needs to be carefully discussed. For instance, to what extent how can we disentangle the impact of a given ethnic origin from the influence of social background ? To what extent is our ability to do so limited by data restrictions?

In the rest of this section, I try to fill-in this gap and discuss three related and commonly used measures of ethnic disadvantage. Each corresponds to a distinct notions of equality of opportunity that I refer to, respectively, as strong equality of opportunity, equal social inequality and non-discrimination on the labor market. In the discussion of these notions of equality of opportunity, I rely on the general discussion of equality of opportunity developed in Lefranc, Pistolesi and Trannoy (2006).

\subsection{Strong equality of opportunity}

To begin with, consider the most inclusive notion of ethnic disadvantage, i.e the notion of "gross" ethnic disadvantage previously mentioned. This notion rests on a very demanding notion of equality of opportunity that I will refer to as strong equality of opportunity.

In general terms, any conception of equality of opportunity amounts to draw a distinction between two types of inequality. On the one hand, inequalities that appear as justified for reasons appealing, for instance, to individual desert, merit or talent. On the other hand, inequalities that appear as illegitimate and that resort to what could be called 
irrelevant circumstances 3 Equality of opportunity requires that individuals of equal merit face similar prospects for achievement, regardless of their circumstances.

The difficult matter, for assessing whether ethnic minorities are offered equal opportunities rests in the definition and empirical identification of merit. In this respect, an important view has been expressed, in political theory, in Roemer (1993; 1998) 44 According to this view, unequal achievement can only be seen as morally legitimate if it is the consequence of individual responsible choice. Hence, merit should be defined on the sole basis of individual choice. Conversely, merit should be defined independently of circumstances. Following Roemer, systematic differences in the level of merit between individuals who differ in their circumstances should be seen as the product of circumstances and cannot be ascribed to personal responsibility. Ethnic origin should obviously count as a circumstance. Hence, any difference in the level of effort, talent, diligence, merit ... between natives and ethnic minorities should be seen as the result of ethnic origin and cannot, in this perspective, be considered a legitimate source of inequality. In other words, this rules out, by construction, the possibility that ethnic minorities exhibit less merit. Hence, according to this restrictive notion of individual responsibility, equality of opportunity implies that, on average, ethnic minorities and natives should achieve similar outcomes 5 This suggests that ethnic disadvantage should be measured by the overall achievement gap between natives and ethnic minorities, without any additional control variables.

\subsection{Equal social inequality}

This conception of equality of opportunity is of course particularly demanding. Any disadvantage suffered by ethnic minorities would indicate that equality of opportunity is violated. But this disadvantage may be very diverse in its nature, and not necessarily ethnic in its essence. Hence the gross ethnic disadvantage represents a catchall measure of all the possible sources of socio-economic disadvantage suffered by ethnic minorities.

It should also be stressed that, according to this strong conception of equality of opportunity, ethnicity is not the only relevant circumstance to consider for assessing equality of opportunity. For instance, the strong conception of equality of opportunity also requires that socio-economic achievement be independent of social origin, since individuals cannot be held responsible for their social and family background. This latter condition is of course rarely met in most first-world countries : a long tradition in sociology has abundantly documented the impact of social origin on educational and social status attainment6; a more recent strand of economic research has also documented the impact of origin on the acquisition of income 7 . In this case, the fact that ethnic minorities most often come from a less privileged social origin than the average native implies that their socio-economic achievement will be lower. But this gross ethnic disadvantage may originate in social inequalities in society at large, without reflecting a specific ethnic penalty. In this context, a useful reference situation is the case where individuals with similar social origin face similar prospects for achievement independently of their ethnic origin. I refer to this situation as a case of "equal social inequality". Any deviation from this reference situation indicates that ethnic minorities suffer specifically-ethnic penalties, beyond the

\footnotetext{
${ }^{3}$ This terminology and the analysis developed infra borrows from Roemer (1998).

${ }^{4}$ See also Arneson (1989) and Cohen (1989).

${ }^{5}$ In fact, as argued in Lefranc et al. (2006) and as discussed below, not only should the average achievement be equal among groups with different circumstances, such as ethnicity, but the entire distribution of achievement should also be identical across these groups.

${ }^{6}$ See for instance Shavit and Blossfeld (1993) Breen (2004) for recent comparative assessments.

${ }^{7}$ Solon (1999), Lefranc, Pistolesi and Trannoy (2008)
} 


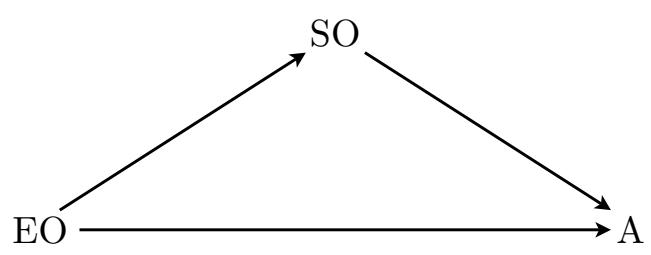

Figure 1: Ethnic origin, social origin and achievement

impact of a less-privileged social origin.

This suggests a second measure of ethnic disadvantage, defined by the achievement gap between ethnic minorities and natives of similar social origin. It corresponds to the following thought experiment : take two individuals who are equally socially advantaged (or disadvantaged) and who only differ by their ethnic origin; what will the achievement gap between these two individuals be. It can be understood as the achievement gap conditional on social origin. This conditional achievement gap represents the difference between the gross ethnic disadvantage referred to in the previous section and the contribution of social inequality to the achievement gap. This can be illustrated by adapting a diagram often used in social mobility studies to discuss the mediating role of education in status transmission. The diagram in figure 1 links ethnic origin (EO) and social origin (SO) to achievement (A). Social inequality in society at large corresponds to the $\mathrm{SO} \rightarrow \mathrm{A}$ link. The gross ethnic disadvantage corresponds to the sum of the indirect impact, mediated by social origin (the $\mathrm{EO} \rightarrow \mathrm{SO} \rightarrow \mathrm{A}$ link) and the residual direct impact of ethnicity on achievement (the $\mathrm{EO} \rightarrow \mathrm{A}$ link). This latter effect is the disadvantage associated with ethnicity once social origin has been controlled for. This second notion comes closer to a measure of the impact of ethnic origin per se. Of course, this measure of ethnic disadvantage still incorporates a wide array of social and economic mechanisms. For instance, ethnic origin can influence socio-economic achievement through its impact on educational attainment, labor force participation decisions or through its influence on labor market outcomes.

A crucial point, in the implementation of this measure of ethnic disadvantage, is to determine what factors should be taken into account when defining social origin. Obviously, social origin should be defined in a broader sense than what is usually considered in social mobility studies. If we take the case of two children, with different ethnicity, and whose parents have similar education and socio-economic status (as usually defined and measured), there could still be, for instance, differences in the social network of their parents. This would influence these children's socio-economic achievement, although ethnicity could not be considered the direct cause of the observed difference in achievement. Hence, one should use a comprehensive definition of social origin that would include in particular accurate measures of parental social, cultural and economic capital.

\subsection{Non-discrimination on the labor market}

The question of labor market discrimination, be it on the basis of ethnicity, race or gender, has attracted a lot of attention in empirical studies 8 From a normative perspective, the absence of discrimination on the labor market represents a minimal requirement of equality of opportunity that comes close to the Rawlsian notion of "careers open to talent", i.e. the requisite that access to jobs be only based on the ability to perform 9

\footnotetext{
${ }^{8}$ A survey of economic research in this area can be found in Altonji and Blank (1999).

${ }^{9}$ Rawls (1971). See Arneson (1999) for a discussion.
} 
Here talent refers to the set of individual characteristics that are relevant to the employment relationship and that determine the individual's ability to perform a given job. And ability to perform helps identify legitimate inequalities, in the definition of equality of opportunity. In most empirical applications, the set of individual characteristics taken into consideration comprises the determinants of individual productivity, which often equates the stock of human capital that the individual is endowed with. In this case, the extent of ethnic disadvantage is defined as the achievement gap between ethnic minorities and natives with similar levels of human capital. Since, the comparison undertaken involves individuals of similar productive characteristics, this gap can then be interpreted as a measure of the extent of discrimination on the labor market 10

This conclusion raises, however, two sets of difficulties. Note first that discrimination in this case is not directly measured but is equated with the residual difference in socioeconomic outcomes, once human capital has been controlled for. One first problem with this interpretation is that the residual gap may also reflect the impact of some residual differences in human capital that have not been properly controlled for when comparing ethnic minorities and natives. In most studies, human capital is generally proxied by educational attainment and labor market experience. Given educational attainment and experience, there remains considerable unobserved heterogeneity in the level of human capital. If the unobserved heterogeneity is correlated with ethnicity, the interpretation of the ethnic disadvantage, conditional on observed human capital, as a measure of discrimination is not valid. The evidence provided in Neal and Johnson (1996) supports this criticism, in the context of racial wage differentials in the US.

The second limitation is that, contrary to the standard neo-classical equilibrium model, in the presence of information imperfection, labor market outcomes are not solely determined by individual productivity. Hence, controlling for the stock of human capital may not suffice to isolate the contribution of discrimination to the discrepant outcomes of natives and minorities. For instance, the economic theory of job search (Mortensen, 1986) together with the empirical analysis of the employment process (Granovetter, 1974) has underlined the role of information on job opportunities in shaping labor market outcomes. This information will not only condition access to jobs but will also influence earnings 11 For instance, a worker with good access to information on job vacancies will stay unemployed for a shorter period of time. Furthermore, since he faces more job opportunities, he will also be less likely to accept low-paying jobs. If there exists differences across ethnic groups regarding information on job opportunities, this may result in different labor market outcomes, even among individuals with similar human capital 12 Assessing discrimination on the labor market thus also ideally requires to control for some measure of individual social capital, to the extent that it is relevant in shaping individual outcomes.

As discussed in this section, there are several ways to define and measure the socioeconomic advantage suffered by ethnic minorities. Each of them refer to a specific conception of what equality of opportunity between ethnic minorities and natives requires and,

\footnotetext{
${ }^{10}$ Since the measure of ethnic disadvantage is only based on individual outcomes, without any information on the processes that led to these outcomes, it is not possible, however to disentangle the various source of labor market discrimination (intentional or unintentional, taste based, statistical, ...) discussed for instance in Veenman (2007)

${ }^{11}$ The consequence of the imperfect observability of workers' productive characteristics by the employer has been emphasized since the seminal work of Arrow (1972). The use of ethnicity as a predictor of individual outcome, given observable productivity traits is of course a clear case of discrimination. In the presence of job search imperfection, on the other hand, two individuals with different ethnic origin and similar human capital can experience different outcomes even in the absence of discrimination.

${ }^{12}$ The role of imperfect information on job opportunities, in the presence of discriminatory employers has been studied in Black (1995).
} 
taken together, they provide a complementary perspective on the different mechanisms that generate the socio-economic disadvantage suffered by ethnic minorities.

\section{Related literature}

It is commonly believed that the absence of data on ethnicity makes the analysis of ethnic disadvantage in France impossible. For certain, the collection of data on ethnic origin in France has triggered recurrent controversies and strong opposition both in the academic world and in the political sphere. But the belief that data on ethnicity is not available in France is, however, largely inaccurate. Data sources exist that allow one to examine the disadvantage suffered by ethnic minorities, although its analysis is very recent and empirical evidence is still limited. In this section, I will briefly review available data and empirical studies of the impact of ethnicity on socio-economic outcomes in France 13

The principles that govern the collection of data relative to ethnicity, as well as geographic and national origin and the data available for measuring ethnic disadvantage in France are discussed in Héran (2002). Self-reported ethnicity is never available in large scale representative surveys in France 14 Information on individual nationality (both current and at birth) and country of birth is available in several major data sets including population census and labor force surveys. On the contrary, with only very few exceptions, foreign ancestry is not documented. Among large scale representative surveys, the major exceptions are the Mobilité géographique et insertion sociale (MGIS - geographic mobility and social integration) survey collected in 1992 (Tribalat, 1996), the 1999 Etude de l'histoire familiale (EHF - survey of family history), and the Formation-QualificationProfession (FQP - Education-training-occupation) survey collected in 1993 and 2003. In all three surveys, information is collected on the country of birth of the parents.

An important contribution to the analysis of the labour market outcomes of immigrants and their descendants, is the work of Meurs, Pailhé and Simon (2006). Based on the EHF survey, they provide detailled evidence on labor force participation, unemployment and access to employment for different generations of immigrants in France. The analysis is conducted separately by country of origin. Despite its great interest, this work is representative of two limitations commonly find in the analysis the impact of ethnic origin on labor market outcomes in France. First, most analysis are concerned with access to employment and very few studies have analyzed the impact of ethnicity on wages and earnings. This is largely due to the lack of information on this important aspect of economic achievement in the above mentioned data sets. A notable exception is Aeberhardt and Pouget (2006) that analyzes wage differentials by ethnic origin. However, as the authors acknowledge, the use of business survey data raises serious concerns about the representativeness of their results. 15

The second limitation of most studies of ethnic disadvantage in France lies in the identification of the ethnic origin of second generation immigrants. In almost all cases, ethnic origin is defined using information on parental country of birth only. For those

\footnotetext{
${ }^{13}$ Besides research focusing solely on France, there also exists several comparative assessment of the achievement of second-generation immigrants, both in education (Corten and Dronkers, 2004; EUMC, 2004; OECD, 2006) and on the labor market (Heath and Cheung, forthcoming; Fleischmann and Dronkers, 2007).

${ }^{14}$ For a pilot survey of self-declaration of ethnicity, on a non-representative sample, see Simon and Clément (2006).

${ }^{15}$ The sample is restricted to individuals working in firms with at least 10 employees and excludes important industries such as agriculture, public administration and personal service activities. Lastly, the sampling design implies that short-duration jobs will be excluded from the analysis. As in most other studies, ethnic origin is defined on the basis of parental country of birth, which is likely to introduce further biases.
} 
whose parents were born in one of the previous French colonies, information on parental country of birth is largely equivocal. It confuses two ethnically diverse populations : on the one hand, the children of ex-colonists; on the other hand, the children of the autochtonous population of those ex-colonies. The first group is too a very large extent, of European ancestry (French - in particular from the eastern region of Alsace, Spanish, Italian, but also German and Swiss). The second is of arabic and berber origins. During the colonial period, these two populations were granted different civil rights, and were culturally, linguistically and socially diverse. Hence, one should expect there descendants to be offered markedly different prospects on the labor market. Distinguishing these two groups is of paramount importance in the case of individuals originating from Algeria, a country that was both a major source of emigration to France and the primary French colony of settlement. As documented in great details in Alba and Silberman (2002), the descendants of French colonists amount to about one half of the second generation immigrants originating from North-Africa. Hence, pooling the two groups together will most likely lead to underestimate the current disadvantage of the children of North-African nationals. Yet, this issue has remained largely understudied and very little effort has been devoted to evaluating the extent of this bias and to providing a comprehensive account of the labor market outcomes of this latter group 16

In more specific contexts, some studies have been able to use detailed information on parental nationality at birth to precisely identify second generation immigrants. This is for instance the case in Canaméro, Canceill and Cloarec (2000), but the analysis is restricted to exit from unemployment and is based on a non-representative data set that only allows to distinguish European and non-European origins 17 Several studies, including Brinbaum and Werquin (2004), Boumahdi and Giret (2005) and Silberman, Alba and Fournier (2007) have also examined school-to-work transitions and early labor market outcomes using detailed information ethnic origin 18 However, these studies focus on early labor market experiences, which represents a very specific insertion period. Hence, their results can hardly be generalized to assess the labor market outcomes of the secondgeneration population.

The rest of this paper offers a comprehensive analysis of the labor market outcomes of second-generation immigrants from North Africa and Southern Europe and offers a careful study of the impact of geographic and national origin on individual achievement.

\section{Data and methodology}

\subsection{Data description}

Our data are taken from the latest wave of the Formation-Qualification-Profession (FQP - Education-Training-Occupation) surveys conducted by the French National Sta-

\footnotetext{
${ }^{16}$ The only exception that I am aware of is the work of Silberman and Fournier (forthcoming) developed simultaneously and independently of the present paper. The two papers differ in several important respects. While their work offers a separate analysis of the outcomes of maghrebins and repatriates, they are not explicitly concerned with the evaluation of the bias that arises from pooling both groups. Furthermore, they adopt a less comprehensive set of measures of ethnic disadvantage than the one used in the empirical section of this paper. Lastly both papers differ in various points in methods, sample definitions and explained variables.

${ }^{17}$ The analysis is based on the Trajectoire des demandeurs d'emploi survey (TDE) that samples registered unemployed workers in three (out of twenty two) French regions - Ile-de-France, Nord-Pas-de-Calais, Provence-Alpes-Côte d'Azur.

${ }^{18}$ All these studies use longitudinal surveys ("Génération" and EVA) that follow a cohort of school leavers. Individuals who report their parents are foreign citizens or have acquired French nationality, are asked about their parents' country of birth.
} 
tistical Agency (INSEE). It was conducted in 2003 and provides a sample of about 40000 individuals. This sample is representative of the French adult population, between 18 and 65 years old.

This survey has been the primary data source for studies of social and intergenerational mobility in France, as well as a wide range of labor market issues. It contains detailed information on education, labor market outcomes (industry, occupation, number of months worked full- and part-time and annual earnings in the previous year). It also provides data on social origin (including both parents occupation and education). In this study, I concentrate four distinct socio-economic outcomes to measure ethnic disadvantage : educational attainment; labor force participation; unemployment; earnings. All four outcomes represent important steps in the process of earnings acquisition.

For our purpose the major advantage of the 2003 wave of the FQP survey is the information it provides on geographic and national origin. All individuals are asked to report their own country of birth and nationality, together with the country of birth and nationality at birth of both parents. In the public-use files, the different countries are grouped in larger geographic areas : Europe (North and West, South, East), North Africa (i.e Algeria, Morocco and Tunisia), other African countries, the Indochinese peninsula (Cambodia, Laos and Vietnam), the Middle East, and the rest of the world.

Since the focus of this paper is on second-generation immigrants, the sample only retains individuals born in France and aged 20 to 50 years old as of the survey date. Based on geographic and national origin, we define a first group, that we refer to as natives, composed of individuals born in France and whose parents were born in France with French nationality. Among individuals whose parents were born outside France, we distinguish two groups according to parents' geographic origin : Southern Europe and North Africa. More precisely, individuals are considered second-generation immigrants from Southern Europe (respectively North-Africa) if they have at least one parent who was born in a country of Southern Europe (resp. North-Africa) 19 The composition of our sample by geographic and national origin is given in table 1, Southern Europe and North Africa represent the two largest second-generation immigrant groups in our with respectively about 1100 and 1400 observations and a total share of about 5 and $7 \%$ of the total population. Groups originating from other geographic areas, on the contrary are all of relatively small size and cannot be analyzed here.

This definition of second-generation immigrants on the basis of geographic origin is similar to the one adopted in most French studies. However, as already discussed, using only information on parental country of birth will lead to confuse heterogeneous ethnic groups, in particular for individuals originating from France's former colonies. Hence we divide the two groups of individuals with foreign geographic origins according to the nationality at birth of their parents : on the one hand, the individuals with a least one parent who is a national at birth of the country of birth; on the other hand, individuals whose parents were not a national of the corresponding geographic area.

For each geographic area, table1 gives the percentage of individuals in our sample who report at least one parent with the matching nationality. The correspondence between geographic origin and national origin is good for individuals originating from Southern

\footnotetext{
${ }^{19}$ Consequently, this study pools together children of mixed couples and single origin individuals. Among individuals with North-African origins, there appears to be a large fraction (more than one half) of mixed couple among pieds noirs. This proportion is much smaller (around 30\%) among individuals with maghrebin origins. In most cases, the outcomes of mixed and single origin individuals are not statisically different. This result could be partly explained by the relatively small size of our sub-samples and requires further analysis.
} 
Table 1: Sample composition, by geographic and national origin

\begin{tabular}{lrcc}
\hline \hline Geographic origin & Frequency & $\begin{array}{c}\text { Share of total population } \\
\text { (in \%, weighted) }\end{array}$ & $\begin{array}{c}\text { Share w/ corresponding } \\
\text { national origin } \\
\text { (in \%, weighted) }\end{array}$ \\
\hline Natives & 19145 & 84.55 & 100 \\
Northern Europe & 288 & 1.31 & 52.78 \\
Southern Europe & 1137 & 5.12 & 81.08 \\
Eastern Europe & 166 & 0.71 & 72.37 \\
North Africa & 1431 & 6.89 & 33.82 \\
Africa (other countries) & 103 & 0.55 & 32.49 \\
Middle East & 49 & 0.27 & 51.65 \\
Indochina & 73 & 0.38 & 27.16 \\
Other & 39 & 0.21 & 55.84 \\
& & & \\
Total & 22431 & 100 & \\
\hline \hline
\end{tabular}

Europe : more than $80 \%$ of those who report at least one parent born in Southern Europe report that at least one of their parents was a national from Southern Europe, at birth.

For individuals originating from the French former colonies, the fit is much lower. Only one third of those who report having one parent born in North Africa also report having one parent who was a national of this geographic area. Note that this is precisely the group of individuals with likely autochthonous North African origins. Furthermore, as reported in the pilot survey of Simon and Clément (2006), this group is very likely to self classify as having North African ethnic origins (Arab or Berber origins). On the contrary, those whose parents were born in North Africa but were not nationals of this area is a composite group that will include former French colonists, other European settlers who emigrated from North-Africa to France, and, to some extent, harkis (i.e. Algerians enrolled in the French army during the war of independence) who where ex post granted the status of citizens by birth 20 In the rest of this paper, we will refer to the former group as maghrebins and to latter as pieds-noirs. It should be noted that the percentage of individuals belonging to the first group (34\%) is slightly lower than the one reported in Alba and Silberman (2002) (46\%)21 One possible explanation for this difference is that the latter is based on direct census reports by the parents of their nationality at birth, while the former is based on children's reports of their parents' nationality at birth. Hence, it is likely to incorporate some measurement error.

\subsection{Methodology}

As discussed in section 2, ethnic disadvantage can be measured by comparing the outcomes of ethnic minorities and natives, keeping some other relevant determinants constant. This can be easily performed using regression analysis. Furthermore, the different notions of ethnic disadvantage previously discussed can identified by changing the list of control variables in the regression.

In order to estimate the gross ethnic disadvantage, I regress individual outcomes on

\footnotetext{
${ }^{20}$ See Alba and Silberman (2002) for a more detailed analysis.

${ }^{21}$ This percentage is computed for cohorts born between 1958 and 1982, based on the cohort sizes reported in Alba and Silberman (2002).
} 
a set of dummy variables for ethnic origin and a single control variable : age 22 The reason for controlling for age is twofold. First, natives and ethnic minorities are likely to exhibit different age structures. Second, individual outcomes - education, unemployment or earnings - are to some extent determined by life-cycle effects. Since age is not a fixed individual characteristic, comparing individuals at different stages of their life-cycle would not provide a meaningful measure of the opportunity gap.

To determine whether the gross ethnic disadvantage is determined by differences in social background between natives and ethnic minorities, I further control for social origin in the regressions. Social origin is measured by parental occupation and education. For both variables, I use a detailed 2-digit classification. I also include in the regression interaction terms between, for each parent, occupation and education, and between the occupation of both parents, with the aim to provide the richest possible characterization of social origin.

To measure the extent of labor market discrimination in access to employment and earnings, I provide two sets of regressions. The first one controls for the individual's level of education, using, again a detailed classification. The second set of regression further adds a control for social origin, in order to proxy for individual social capital, since, as discussed in section 2, social capital may also influence labor market outcomes.

\section{Results}

\subsection{Educational attainment}

To measure the effect of ethnic origin on educational attainment, I regress the highest degree obtained on dummy variables for ethnic origin, using ordered probit regression models. I consider four distinct educational levels : lower secondary education degree or less, vocational secondary education, upper secondary education (baccalauréat) and higher education degree. The sample consists of all individuals between 20 and 50 years old 23 In figure 2, the definition of ethnic origin is only based on parent's country of birth. Figure 3 takes parental nationality into account.

For females, without taking social origin into account, the difference in educational attainment between natives and second generation immigrants for both Southern Europe and North Africa appears very small. On average, the share of natives achieving the highest (respectively lowest) level of education is $2 \%$ higher (resp. lower) than for second-generation immigrant of similar age. Lastly, there appears to be little differences according to origin (Figure 2, panel A-1): the distribution of education is very similar for second-generation migrants, regardless of whether they originate from Southern Europe of North Africa. This is no longer true when taking parental nationality into account. Second-generation immigrants from Southern Europe perform similarly regardless of the nationality of their parents. On the contrary, there are large differences, among individuals of North African origins, between pieds noirs and maghrebins (Figure 3, panel A-1), with the former performing better than natives and the latter markedly worse. These differences in educational achievement are largely attributable to social origin. After controlling for parental socio-economic status and education, female second-generation immigrants appears to perform better, in terms of education, than native women. And this difference is statistically significant. On the other hand, women with North African geographic and/or

\footnotetext{
${ }^{22}$ More precisely, age is entered as a second order polynomial.

${ }^{23}$ It also includes individual still in full-time education, for which the education level is the highest degree attained as of the survey date.
} 
Figure 2: Educational attainment by ethnic origin (country) A - Female

1 - conditional on age

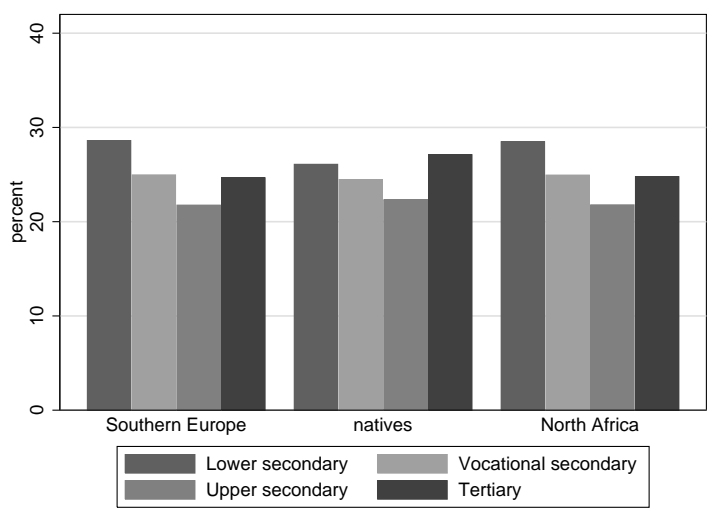

2 - conditional on age and social origin

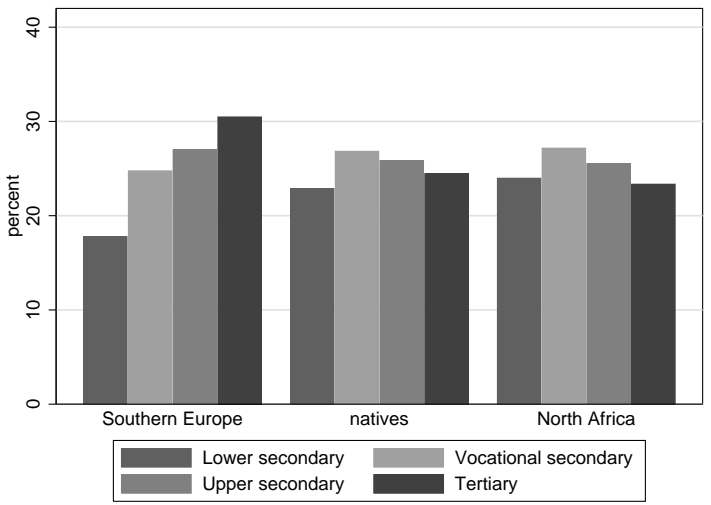

B - Male

1 - conditional on age

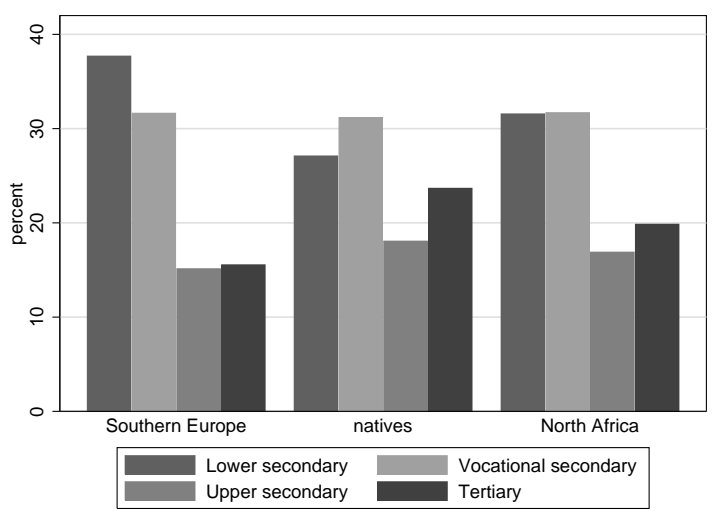

2 - conditional on age and social origin

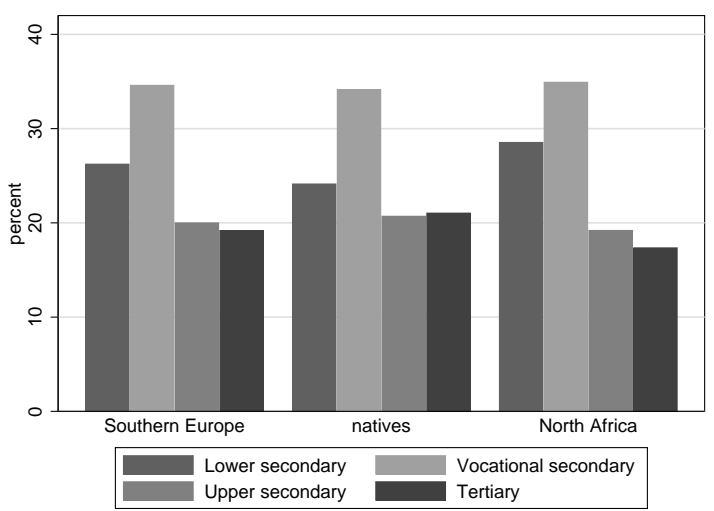


Figure 3: Educational attainment by ethnic origin (nationality)

A - Female

1 - conditional on age

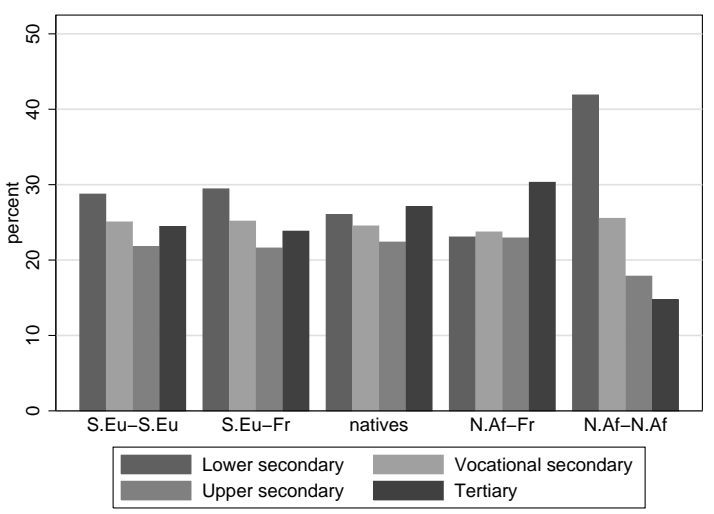

2 - conditional on age and social origin

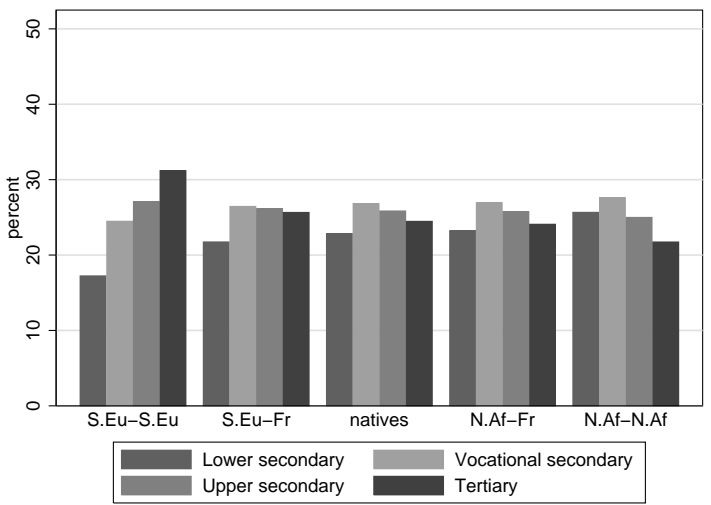

B - Male

1 - conditional on age

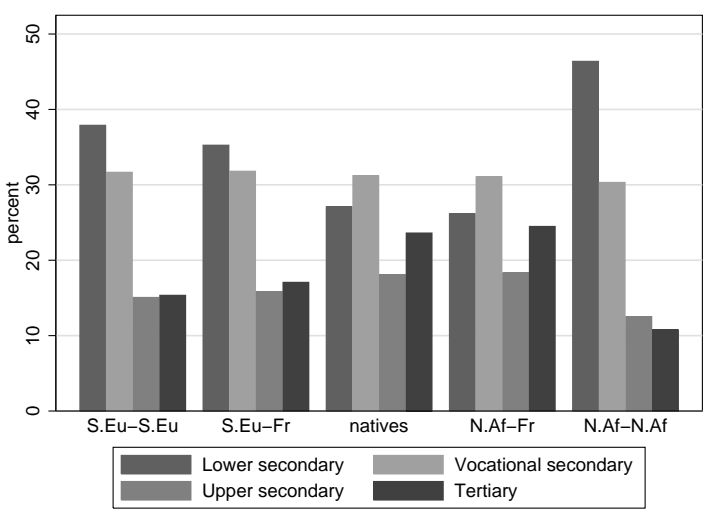

2 - conditional on age and social origin

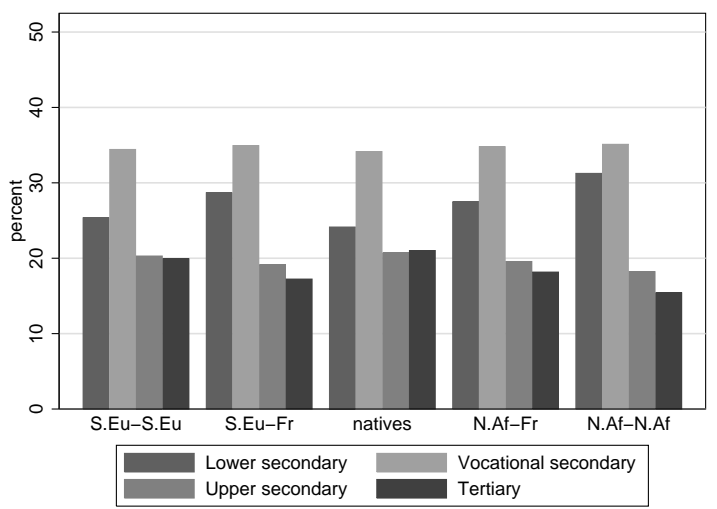


national origins reach slightly lower educational levels than natives but the difference is not statistically significant (Figures 2 and 3 , panel A-2).

For males, we also find that, without taking social origin into account, second-generation migrants reach lower educational level than natives but the differences are larger than for females. The percentage reaching the highest level of education amounts to $23 \%$ for natives, compared to $15 \%$ for individuals with Southern European origins and $10 \%$ for Maghrebin second-generations. For the lowest level of education, these percentages are respectively 27, 37 and 46\% (Figure 3, panel B-1). Controlling for social origin strongly reduces this achievement gap. After control, the only group that reaches significantly lower educational level than natives is the group of Maghrebin origins (Figure 3, panel B-2). After controlling for social origin, the latter group is still $6 \%$ less (resp. $7 \%$ more) likely to reach the highest (resp. the lowest) level of education than natives.

Hence, the results obtained here slightly differ from the ones reported in ?. In their analysis of the odds of high-school graduation, using longitudinal data, they conclude that, conditional on social background and school achievement at the beginning of secondary education, immigrants' children tend to be more successful than natives. Our results indicate that this conclusion is only valid for one specific subgroup : female second-generation immigrants with South European origins. For most other groups there are no significant differences with natives but in some cases second-generation migrants may succeed significantly less than natives, both statistically and quantitatively 24

\subsection{Labor force status}

I now examine the labor market integration of second-generation migrants and consider three different outcomes : labor force participation at the time of the survey, unemployment at the time of the survey and access to paid employment over the course of the previous year. In all cases, ethnic penalty is estimated using a probit model. All tables report the marginal effect of ethnic origin, i.e. the difference in probability, compared with native, at the mean value of other control characteristics.

Labor force participation The analysis of labor force participation is conducted on the sample of individuals who are not enrolled in full-time education. This analysis only makes sense for females, since as shown in the panel B of table 2, regardless of the specification used, there is never any statistically significant gap between natives and second-generation immigrants in the participation rate of males.

Females with a Southern Europe geographic origin, have a slightly higher participation rate than natives although the difference is rather small (about 2 points higher, against a reference participation rate of $84 \%$ ) and in most cases not significant. More precisely, for those with a least one parent of Southern European nationality, the difference with the group of natives is never significant and amounts to about 0.7 percentage points, when education and social origin are taken into account.

In the case, of women with a North-African origin, the first striking result is the large and always significant difference between the outcome of pieds noirs and that of maghrebins. While the outcome of the former group is very close to that of natives, the participation rate of the latter group is clearly lower and the difference is strongly

\footnotetext{
${ }^{24}$ Several factors are likely to account for this difference in results. First the data set used in ? does not allow to split children of immigrants according to geographic or national origin. Second, their analysis takes into account educational achievement at the beginning of secondary education to explain success in secondary education. While this makes sense to assess whether children of immigrants face a specific disadvantage in secondary education, this cannot be justified when analyzing their overall educational disadvantage.
} 
Table 2: Probability of labor force participation by ethnic origin

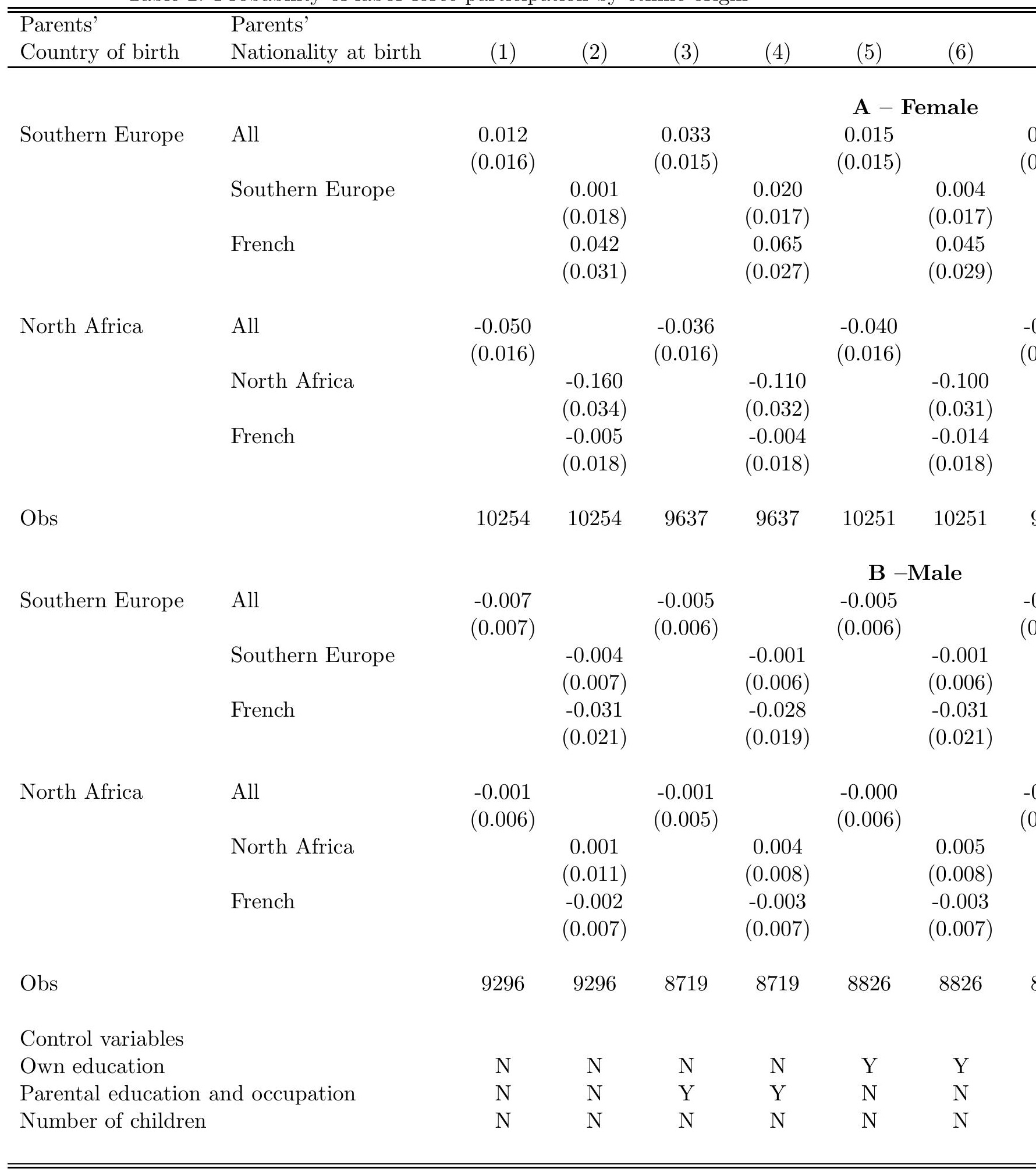


significant. In this instance, looking at the average ethnic penalty over these two subpopulations is clearly misleading, since the conclusion would be that the participation gap is small and in some cases not significant. On the contrary, the participation gap is particularly large. The gross ethnic disadvantage amounts to 16 percentage points (column 2). Compared to women with similar social origin, maghrebin women are still 10 points less likely to participate in the labor market (column 4). After controlling for both social origin and individual human capital, more than half of the gross participation gap remains. Several factors may account for this difference in the participation rate, including family constraints and individual preferences. For this reason, column 10 takes family size into consideration in the participation equation. After controlling for that factor, the participation gap is still close to 7 percentage points. One alternative explanation is that the participation gap reflects lower employment opportunities offered to maghrebin women. This calls for the analysis of other aspects of labor market integration.

Unemployment Table 3 presents the estimated unemployment rate differential, according to origin, for those who participate in the labor force.

The first result to emphasize is the absence of a significant unemployment gap between natives and second-generation immigrants from Southern Europe. In all cases, the unemployment gap is small in magnitude and sometimes even negative (which indicates a lower unemployment rate than for natives). Furthermore, the effect of Southern European origin on the risk of unemployment is never statistically significant.

Individuals with North African origins experience a very different situation, with an unemployment rate more than twice as high as that of natives. For males, the unemployment gap amounts to 11 percentage points (column 2), for a reference unemployment rate among natives of about $6 \% 25$ For females, the gross ethnic disadvantage is even larger and reaches 15 percentage points. One should also emphasize the importance of separating individuals with North African geographic origin according to the nationality of their parents. The gross disadvantage suffered by individuals with maghrebin origin is twice as large as the average disadvantage of people with North African geographic origin and the difference with the pieds noirs population is strongly significant.

To a large extent, this sizeable gross ethnic disadvantage cannot be explained by differences in individual characteristics. For females, the unemployment gap is roughly unchanged, at about $13 \%$, when restricting the comparison to individuals with similar social origin. Controlling for human capital only slightly reduces the unemployment differentials : compared to natives with similar education, women with maghrebin origins still experience a 10 points higher unemployment rate. Individual characteristics explain a larger share of the unemployment differentials in the case of males but still leaves a large unexplained residual. Given education and social origin, males with maghrebin origins are still $6 \%$ more likely to be unemployed.

Lastly, it is also important to note that, to the extent that individual characteristics explain the unemployment gap, male maghrebin suffer more from a having a more disadvantaged social origin than from a less favorable educational attainment : compared to individuals with similar education (column 6), they still face a 8.6 points higher unemployment rate; compared to individuals with similar social origin, the gap is lower (6.7 percentage points).

Paid employment in previous year The unemployment rate differential discussed above may result from two distinct mechanisms : first, a higher risk of becoming unem-

\footnotetext{
${ }^{25}$ The reference unemployment rate is the predicted unemployment rate at the mean sample characteristics, which may differ from the mean unemployment rate in the population under study.
} 
Table 3: Probability of unemployment by ethnic origin

\begin{tabular}{|c|c|c|c|c|c|c|c|c|}
\hline $\begin{array}{l}\text { Parents' } \\
\text { Country of birth }\end{array}$ & $\begin{array}{l}\text { Parents' } \\
\text { Nationality at birth }\end{array}$ & $(1)$ & $(2)$ & $(3)$ & $(4)$ & $(5)$ & $(6)$ & $(7$ \\
\hline & & & \multicolumn{6}{|c|}{ A - Female } \\
\hline \multirow[t]{3}{*}{ Southern Europe } & All & $\begin{array}{c}0.029 \\
(0.015)\end{array}$ & & $\begin{array}{c}0.011 \\
(0.015)\end{array}$ & & $\begin{array}{c}0.025 \\
(0.014)\end{array}$ & & $\begin{array}{r}0.0 \\
(0.0\end{array}$ \\
\hline & Southern Europe & & $\begin{array}{c}0.028 \\
(0.017)\end{array}$ & & $\begin{array}{c}0.009 \\
(0.016)\end{array}$ & & $\begin{array}{c}0.025 \\
(0.016)\end{array}$ & \\
\hline & French & & $\begin{array}{c}0.030 \\
(0.034)\end{array}$ & & $\begin{array}{c}0.022 \\
(0.032)\end{array}$ & & $\begin{array}{c}0.019 \\
(0.030)\end{array}$ & \\
\hline \multirow[t]{3}{*}{ North Africa } & All & $\begin{array}{c}0.075 \\
(0.017)\end{array}$ & & $\begin{array}{c}0.068 \\
(0.017)\end{array}$ & & $\begin{array}{c}0.061 \\
(0.015)\end{array}$ & & $\begin{array}{r}0.0 \\
(0.0\end{array}$ \\
\hline & North Africa & & $\begin{array}{c}0.152 \\
(0.037)\end{array}$ & & $\begin{array}{c}0.127 \\
(0.037)\end{array}$ & & $\begin{array}{c}0.101 \\
(0.033)\end{array}$ & \\
\hline & French & & $\begin{array}{c}0.049 \\
(0.018)\end{array}$ & & $\begin{array}{c}0.048 \\
(0.018)\end{array}$ & & $\begin{array}{c}0.048 \\
(0.017)\end{array}$ & \\
\hline Obs & & 8653 & 8653 & 8145 & 8145 & 8650 & 8650 & 81 \\
\hline \multirow[t]{2}{*}{ Southern Europe } & All & $\begin{array}{c}0.010 \\
(0.012)\end{array}$ & & $\begin{array}{l}-0.005 \\
(0.010)\end{array}$ & B - & $\begin{array}{l}\text { Male } \\
0.000 \\
(0.010)\end{array}$ & & $\begin{array}{l}-0.0 \\
(0.0\end{array}$ \\
\hline & $\begin{array}{l}\text { Southern Europe } \\
\text { French }\end{array}$ & & $\begin{array}{c}0.009 \\
(0.013) \\
0.004 \\
(0.025)\end{array}$ & & $\begin{array}{l}-0.006 \\
(0.010) \\
-0.006 \\
(0.021)\end{array}$ & & $\begin{array}{l}-0.001 \\
(0.011) \\
-0.002 \\
(0.022)\end{array}$ & \\
\hline \multirow[t]{3}{*}{ North Africa } & All & $\begin{array}{c}0.069 \\
(0.015)\end{array}$ & & $\begin{array}{c}0.050 \\
(0.013)\end{array}$ & & $\begin{array}{c}0.058 \\
(0.014)\end{array}$ & & $\begin{array}{r}0.0 \\
(0.0\end{array}$ \\
\hline & North Africa & & $\begin{array}{c}0.115 \\
(0.030)\end{array}$ & & $\begin{array}{c}0.067 \\
(0.025)\end{array}$ & & $\begin{array}{c}0.086 \\
(0.027)\end{array}$ & \\
\hline & French & & $\begin{array}{c}0.051 \\
(0.016)\end{array}$ & & $\begin{array}{c}0.044 \\
(0.016)\end{array}$ & & $\begin{array}{c}0.047 \\
(0.015)\end{array}$ & \\
\hline Obs & & 9117 & 9117 & 8553 & 8553 & 9097 & 9097 & 85 \\
\hline $\begin{array}{l}\text { Control variables } \\
\text { Own education } \\
\text { Parental educatior }\end{array}$ & and occupation & $\begin{array}{l}\mathrm{N} \\
\mathrm{N}\end{array}$ & $\begin{array}{l}\mathrm{N} \\
\mathrm{N}\end{array}$ & $\begin{array}{l}\mathrm{Y} \\
\mathrm{N}\end{array}$ & $\begin{array}{l}\mathrm{Y} \\
\mathrm{N}\end{array}$ & $\begin{array}{l}\mathrm{N} \\
\mathrm{Y}\end{array}$ & $\begin{array}{l}\mathrm{N} \\
\mathrm{Y}\end{array}$ & Y \\
\hline
\end{tabular}


Table 4: Probability of paid employment in previous year by ethnic origin

\begin{tabular}{|c|c|c|c|c|c|c|c|c|c|}
\hline $\begin{array}{l}\text { Parents' } \\
\text { Country of birth }\end{array}$ & $\begin{array}{l}\text { Parents' } \\
\text { Nationality at birth }\end{array}$ & $(1)$ & $(2)$ & (3) & $(4)$ & $(5)$ & $(6)$ & $(7)$ & $(8)$ \\
\hline Southern Europe & All & $\begin{array}{c}0.008 \\
(0.011)\end{array}$ & & $\begin{array}{c}0.016 \\
(0.010)\end{array}$ & $\mathbf{A}-\mathbf{F}$ & $\begin{array}{l}\text { male } \\
0.009 \\
(0.010)\end{array}$ & & $\begin{array}{c}0.010 \\
(0.010)\end{array}$ & \\
\hline & $\begin{array}{l}\text { Southern Europe } \\
\text { French }\end{array}$ & & $\begin{array}{c}-0.001 \\
(0.013) \\
0.046 \\
(0.015)\end{array}$ & & $\begin{array}{c}0.008 \\
(0.012) \\
0.046 \\
(0.013)\end{array}$ & & $\begin{array}{c}-0.000 \\
(0.012) \\
0.043 \\
(0.012)\end{array}$ & & $\begin{array}{c}0.001 \\
(0.013) \\
0.042 \\
(0.012)\end{array}$ \\
\hline \multirow[t]{3}{*}{ North Africa } & All & $\begin{array}{l}-0.070 \\
(0.015)\end{array}$ & & $\begin{array}{l}-0.070 \\
(0.016)\end{array}$ & & $\begin{array}{l}-0.059 \\
(0.014)\end{array}$ & & $\begin{array}{l}-0.060 \\
(0.015)\end{array}$ & \\
\hline & North Africa & & $\begin{array}{l}-0.133 \\
(0.035)\end{array}$ & & $\begin{array}{l}-0.112 \\
(0.035)\end{array}$ & & $\begin{array}{l}-0.088 \\
(0.030)\end{array}$ & & $\begin{array}{l}-0.089 \\
(0.032)\end{array}$ \\
\hline & French & & $\begin{array}{l}-0.050 \\
(0.017)\end{array}$ & & $\begin{array}{l}-0.057 \\
(0.018)\end{array}$ & & $\begin{array}{l}-0.049 \\
(0.016)\end{array}$ & & $\begin{array}{l}-0.052 \\
(0.017)\end{array}$ \\
\hline Obs & & 8653 & 8653 & 8145 & 8145 & 8650 & 8650 & 8142 & 8142 \\
\hline Southern Europe & All & $\begin{array}{c}0.003 \\
(0.008)\end{array}$ & & $\begin{array}{c}0.007 \\
(0.007)\end{array}$ & B - & $\begin{array}{l}\text { Iale } \\
\qquad 0.007 \\
(0.006)\end{array}$ & & $\begin{array}{c}0.007 \\
(0.006)\end{array}$ & \\
\hline & $\begin{array}{l}\text { Southern Europe } \\
\text { French }\end{array}$ & & $\begin{array}{c}0.002 \\
(0.008) \\
0.012 \\
(0.014)\end{array}$ & & $\begin{array}{c}0.006 \\
(0.007) \\
0.012 \\
(0.013)\end{array}$ & & $\begin{array}{c}0.006 \\
(0.007) \\
0.011 \\
(0.012)\end{array}$ & & $\begin{array}{c}0.006 \\
(0.007) \\
0.011 \\
(0.011)\end{array}$ \\
\hline \multirow[t]{2}{*}{ North Africa } & All & $\begin{array}{l}-0.020 \\
(0.010)\end{array}$ & & $\begin{array}{l}-0.014 \\
(0.009)\end{array}$ & & $\begin{array}{l}-0.014 \\
(0.008)\end{array}$ & & $\begin{array}{l}-0.010 \\
(0.008)\end{array}$ & \\
\hline & $\begin{array}{l}\text { North Africa } \\
\text { French }\end{array}$ & & $\begin{array}{l}-0.056 \\
(0.023) \\
-0.006 \\
(0.010)\end{array}$ & & $\begin{array}{l}-0.039 \\
(0.020) \\
-0.002 \\
(0.009)\end{array}$ & & $\begin{array}{l}-0.037 \\
(0.018) \\
-0.004 \\
(0.009)\end{array}$ & & $\begin{array}{l}-0.031 \\
(0.017) \\
-0.001 \\
(0.008)\end{array}$ \\
\hline Obs & & 9117 & 9117 & 8420 & 8420 & 9060 & 9060 & 8366 & 8366 \\
\hline $\begin{array}{l}\text { Control variables } \\
\text { Own education } \\
\text { Parental education }\end{array}$ & and occupation & $\begin{array}{l}\mathrm{N} \\
\mathrm{N}\end{array}$ & $\begin{array}{l}\mathrm{N} \\
\mathrm{N}\end{array}$ & $\begin{array}{l}\mathrm{N} \\
\mathrm{Y}\end{array}$ & $\begin{array}{l}\mathrm{N} \\
\mathrm{Y}\end{array}$ & $\begin{array}{l}\mathrm{Y} \\
\mathrm{N}\end{array}$ & $\begin{array}{l}\mathrm{Y} \\
\mathrm{N}\end{array}$ & $\begin{array}{l}\mathrm{Y} \\
\mathrm{Y}\end{array}$ & $\begin{array}{l}\mathrm{Y} \\
\mathrm{Y}\end{array}$ \\
\hline
\end{tabular}


ployed; second, a lower probability of exiting unemployment. Disentangling the two effects calls for a detailed micro-economic study of unemployment dynamics, which goes beyond the scope of the present paper. An alternative way of addressing this question is to look at labor market status over a longer period of time. Instead of focusing on labor force status at a given point in time, one can for instance examine the chances of having been employed at any point in time over the previous year. The results are presented in table 4.

The results suggests that the employment disadvantage suffered by individuals with North African origins takes a different form for males and for females. For males, the gap in the probability of paid employment in the previous year is much smaller than the gap in the probability of unemployment. On the other hand, for females, the two gaps are of similar magnitudes. This suggests that men mostly suffer from a higher risk of becoming unemployed rather than from a lower risk of job finding. In the case of women, their higher risk of unemployment cannot be predominantly ascribed to one of the two mechanisms discussed above.

\subsection{Earnings}

The analysis of the labor market status of second-generation immigrants provides an incomplete picture of their labor market outcomes. First, it is difficult to assess the welfare consequences of unequal opportunities, on the basis of unemployment or participation rate differentials alone. Second, it is also possible that ethnic minorities face additional ethnic disadvantage, even once they secured access to employment. In this section, we remedy these two limitations by analyzing the earnings and wage differentials between secondgeneration immigrants and natives.

Annual earnings Table 5 presents the differences in annual earnings according to geographic and national origin. It is based on the estimation of earnings regression on all wage-earners who report positive earnings in the year preceding the survey.

Again, the situation of second-generation immigrants of Southern European origins is very close to that of natives. The gross ethnic earnings disadvantage amounts to about $6 \%$ for females and $2 \%$ for males and is hardly statistically significant. Taking social origin into account, this disadvantage turns into a positive (and significant) advantage : for instance males earn about $6 \%$ more than natives with similar ethnic background. Of course, as already discussed, several mechanisms can trigger this overall advantage. Comparing columns 6 and 10 suggests that in the case of males with Southern European origins, it is mostly related to their labor market outcomes and not to a more favorable endowment in human capital. In fact, this groups also performs better than natives at the same level of education.

This situation stands in marked contrast with that of second-generation maghrebins who experience significantly lower annual earnings than natives. The gross ethnic disadvantage amounts to $19 \%$ for females and raises to $22 \%$ for males (column 2). Again, not taking parental nationality into consideration would lead to seriously underestimate the earnings disadvantage of this group (column 1). Although the earnings gap is of comparable magnitude for males and females, its interpretation differs. In the case of males, this gap can hardly be explained by differences in individual characteristics. If we compare male maghrebins to natives with similar social origin, they still suffer a $13 \%$ earnings gap. Comparing them to natives with similar education leaves an earnings gap of $15 \%$. This is what most studies would consider as potential discrimination. However, as indicated in column 10, social origin matters for labor market outcomes even once education is taken 
Table 5: Annual earnings differentials by ethnic origin

\begin{tabular}{|c|c|c|c|c|c|c|c|c|c|c|c|}
\hline $\begin{array}{l}\text { Parents' } \\
\text { Country of birth } \\
\end{array}$ & $\begin{array}{l}\text { Parents' } \\
\text { Nationality at birth }\end{array}$ & $(1)$ & $(2)$ & $(3)$ & $(4)$ & $(5)$ & $(6)$ & $(7)$ & $(8)$ & $(9)$ & $(10)$ \\
\hline \multirow[t]{2}{*}{ Southern Europe } & All & $\begin{array}{l}-0.063 \\
(0.034)\end{array}$ & & $\begin{array}{r}0.003 \\
(0.036)\end{array}$ & & $\begin{array}{c}\mathbf{A}-\mathbf{F} \\
-0.039 \\
(0.031)\end{array}$ & male & $\begin{array}{r}-0.014 \\
(0.029)\end{array}$ & & $\begin{array}{r}-0.039 \\
(0.033)\end{array}$ & \\
\hline & $\begin{array}{l}\text { Southern Europe } \\
\text { French }\end{array}$ & & $\begin{array}{r}-0.048 \\
(0.038) \\
-0.116 \\
(0.073)\end{array}$ & 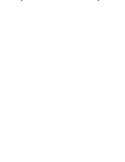 & $\begin{array}{r}0.030 \\
(0.040) \\
-0.087 \\
(0.074)\end{array}$ & & $\begin{array}{r}-0.026 \\
(0.035) \\
-0.075 \\
(0.067)\end{array}$ & & $\begin{array}{r}0.001 \\
(0.032) \\
-0.061 \\
(0.062)\end{array}$ & & $\begin{array}{r}-0.018 \\
(0.037) \\
-0.097 \\
(0.069)\end{array}$ \\
\hline North Africa & All & $\begin{array}{l}-0.055 \\
(0.034)\end{array}$ & & $\begin{array}{r}-0.071 \\
(0.034)\end{array}$ & & $\begin{array}{c}-0.040 \\
(0.031)\end{array}$ & & $\begin{array}{c}-0.054 \\
(0.028)\end{array}$ & & $\begin{array}{r}-0.048 \\
(0.032)\end{array}$ & \\
\hline & $\begin{array}{l}\text { North Africa } \\
\text { French }\end{array}$ & & $\begin{array}{r}-0.192 \\
(0.066) \\
-0.010 \\
(0.038)\end{array}$ & & $\begin{array}{r}-0.090 \\
(0.068) \\
-0.064 \\
(0.039)\end{array}$ & & $\begin{array}{r}-0.070 \\
(0.061) \\
-0.030 \\
(0.035)\end{array}$ & & $\begin{array}{r}-0.077 \\
(0.056) \\
-0.045 \\
(0.032)\end{array}$ & & $\begin{array}{r}-0.060 \\
(0.064) \\
-0.043 \\
(0.037)\end{array}$ \\
\hline $\begin{array}{l}\text { Obs } \\
\text { R-sq }\end{array}$ & & $\begin{array}{l}7722 \\
0.03\end{array}$ & $\begin{array}{r}7722 \\
0.03\end{array}$ & $\begin{array}{r}7279 \\
0.09\end{array}$ & $\begin{array}{r}7279 \\
0.09\end{array}$ & $\begin{array}{r}7722 \\
0.18\end{array}$ & $\begin{array}{r}7722 \\
0.18\end{array}$ & $\begin{array}{r}7722 \\
0.31\end{array}$ & $\begin{array}{r}7722 \\
0.31\end{array}$ & $\begin{array}{r}7279 \\
0.20\end{array}$ & $\begin{array}{r}7279 \\
0.20\end{array}$ \\
\hline Southern Europe & All & $\begin{array}{l}-0.021 \\
(0.025)\end{array}$ & & $\begin{array}{r}0.058 \\
(0.025)\end{array}$ & & $\begin{array}{r}\text { B - } \\
0.034 \\
(0.022)\end{array}$ & & $\begin{array}{r}0.026 \\
(0.021)\end{array}$ & & $\begin{array}{r}0.053 \\
(0.023)\end{array}$ & \\
\hline & $\begin{array}{l}\text { Southern Europe } \\
\text { French }\end{array}$ & & $\begin{array}{r}-0.022 \\
(0.027) \\
-0.015 \\
(0.056)\end{array}$ & & $\begin{array}{r}0.065 \\
(0.027) \\
0.030 \\
(0.055)\end{array}$ & & $\begin{array}{r}0.037 \\
(0.024) \\
0.023 \\
(0.050)\end{array}$ & & $\begin{array}{r}0.030 \\
(0.022) \\
0.010 \\
(0.047)\end{array}$ & & $\begin{array}{r}0.058 \\
(0.025) \\
0.032 \\
(0.051)\end{array}$ \\
\hline North Africa & All & $\begin{array}{l}-0.084 \\
(0.025)\end{array}$ & & $\begin{array}{r}-0.103 \\
(0.025)\end{array}$ & & $\begin{array}{r}-0.085 \\
(0.022)\end{array}$ & & $\begin{array}{r}-0.101 \\
(0.021)\end{array}$ & & $\begin{array}{r}-0.091 \\
(0.023)\end{array}$ & \\
\hline & $\begin{array}{l}\text { North Africa } \\
\text { French }\end{array}$ & & $\begin{array}{r}-0.222 \\
(0.046) \\
-0.031 \\
(0.029)\end{array}$ & & $\begin{array}{r}-0.134 \\
(0.046) \\
-0.092 \\
(0.029)\end{array}$ & & $\begin{array}{r}-0.153 \\
(0.041) \\
-0.060 \\
(0.026)\end{array}$ & & $\begin{array}{r}-0.135 \\
(0.039) \\
-0.088 \\
(0.024)\end{array}$ & & $\begin{array}{r}-0.130 \\
(0.043) \\
-0.077 \\
(0.027)\end{array}$ \\
\hline $\begin{array}{l}\text { Obs } \\
\text { R-sq }\end{array}$ & & $\begin{array}{l}7967 \\
0.10\end{array}$ & $\begin{array}{r}7967 \\
0.10\end{array}$ & $\begin{array}{r}7472 \\
0.20\end{array}$ & $\begin{array}{r}7472 \\
0.20\end{array}$ & $\begin{array}{r}7966 \\
0.29\end{array}$ & $\begin{array}{r}7966 \\
0.29\end{array}$ & $\begin{array}{r}7966 \\
0.38\end{array}$ & $\begin{array}{r}7966 \\
0.38\end{array}$ & $\begin{array}{r}7471 \\
0.32\end{array}$ & $\begin{array}{r}7471 \\
0.32\end{array}$ \\
\hline $\begin{array}{l}\text { Control variables } \\
\text { Own education } \\
\text { Own occupation } \\
\text { Parental education }\end{array}$ & and occupation & $\begin{array}{l}\mathrm{N} \\
\mathrm{N} \\
\mathrm{N}\end{array}$ & $\begin{array}{l}\mathrm{N} \\
\mathrm{N} \\
\mathrm{N}\end{array}$ & $\begin{array}{l}\mathrm{N} \\
\mathrm{N} \\
\mathrm{Y}\end{array}$ & $\begin{array}{l}\mathrm{N} \\
\mathrm{N} \\
\mathrm{Y}\end{array}$ & $\begin{array}{l}\mathrm{Y} \\
\mathrm{N} \\
\mathrm{N}\end{array}$ & $\begin{array}{l}\mathrm{Y} \\
\mathrm{N} \\
\mathrm{N}\end{array}$ & $\begin{array}{l}\mathrm{Y} \\
\mathrm{Y} \\
\mathrm{N}\end{array}$ & $\begin{array}{l}\mathrm{Y} \\
\mathrm{Y} \\
\mathrm{N}\end{array}$ & $\begin{array}{l}\mathrm{Y} \\
\mathrm{N} \\
\mathrm{Y}\end{array}$ & $\begin{array}{l}\mathrm{Y} \\
\mathrm{N} \\
\mathrm{Y}\end{array}$ \\
\hline
\end{tabular}


into account. Nevertheless, after taking differences in both education and social origin into account, more than half of the initial earnings gap persist.

Females with maghrebin origins face a different situation since for them, differences in social origin and education explain more than two thirds of the $19 \%$ gross earnings differentials. Compared to natives with similar education and social origin, they earn about $6 \%$ less per year. Given that this differential is relatively small and is not statistically significant, it would be tempting to conclude that there is little discrimination at work against maghrebin females. However, one should emphasize that the estimations in 5 are conducted on the sample of individuals with positive earnings in the year preceding the survey. Hence they are conducted on the selected sample of labor market participants who were able to access employment over that time period. As we previously discussed, even controlling for education and origin, maghrebin females face markedly lower chances of both labor force participation and employment.

Full-time full-year equivalent earnings Differences in annual earnings can arise because of differences in wages or in the amount of time worked during the year. To assess the relative contribution of these two factors, I last compare the value of full-time full-year equivalent earnings between natives and second generation ethnic minorities. To compute full-time full-year equivalent earnings, I divide annual earnings by the number of months worked, weighted by work duration.

For individuals with South European origins, the results are very similar to those of the previous section. The small gross earnings disadvantage turns into a small positive advantage of about $4 \%$ once social origin and education are taken into account. This suggests that roughly two thirds of the overall $6 \%$ earnings advantages comes from higher wages 26

The gross ethnic disadvantage of second-generation maghrebins, is again large, around $10 \%$. However, contrary to the annual earnings differential, most of this gap can be ascribed to differences in education and social origin. Once this two dimensions are taken into account, the residual differential is lower than $2 \%$ and is not significant. This indicates that the annual earnings differentials is mostly determined by differences in access to employment and in the number of hours worked, rather than by a difference in wages.

\section{Discussion and conclusion}

The analysis of the previous section reveals the great heterogeneity in the socioeconomic achievement of second-generation immigrants, according to their ethnic origin. Among the groups studied in this paper, one groups suffers a particularly large ethnic disadvantage. This groups consists of the children of North African immigrants. For this group, earnings expectations fall about $20 \%$ short of those of natives of similar age. Given the relatively low degree of earnings inequality on the French labor market this overall ethnic disadvantage represents a rather large earnings penalty. The overall earnings disadvantage suffered by male and female second-generation immigrants from North Africa is of similar magnitude. It should be noted though that, in this study, I have compared female ethnic minorities with female natives. Given the extent of the gender gap (Meurs and Ponthieux, 2000), the disadvantage suffered by female North-African minorities is thus particularly large.

\footnotetext{
${ }^{26}$ One limitation of the FQP survey, in this respect, is that it does not provide the actual number of hours worked. The information available is whether the job is worked fulltime or part-time, and in this latter case, what share in percentage of a fulltime job. Hence the higher wage found here can also reflect differences in the extensive margin, for instance a higher number of overtime hours.
} 
Table 6: Full-time full-year equivalent earnings differentials by ethnic origin

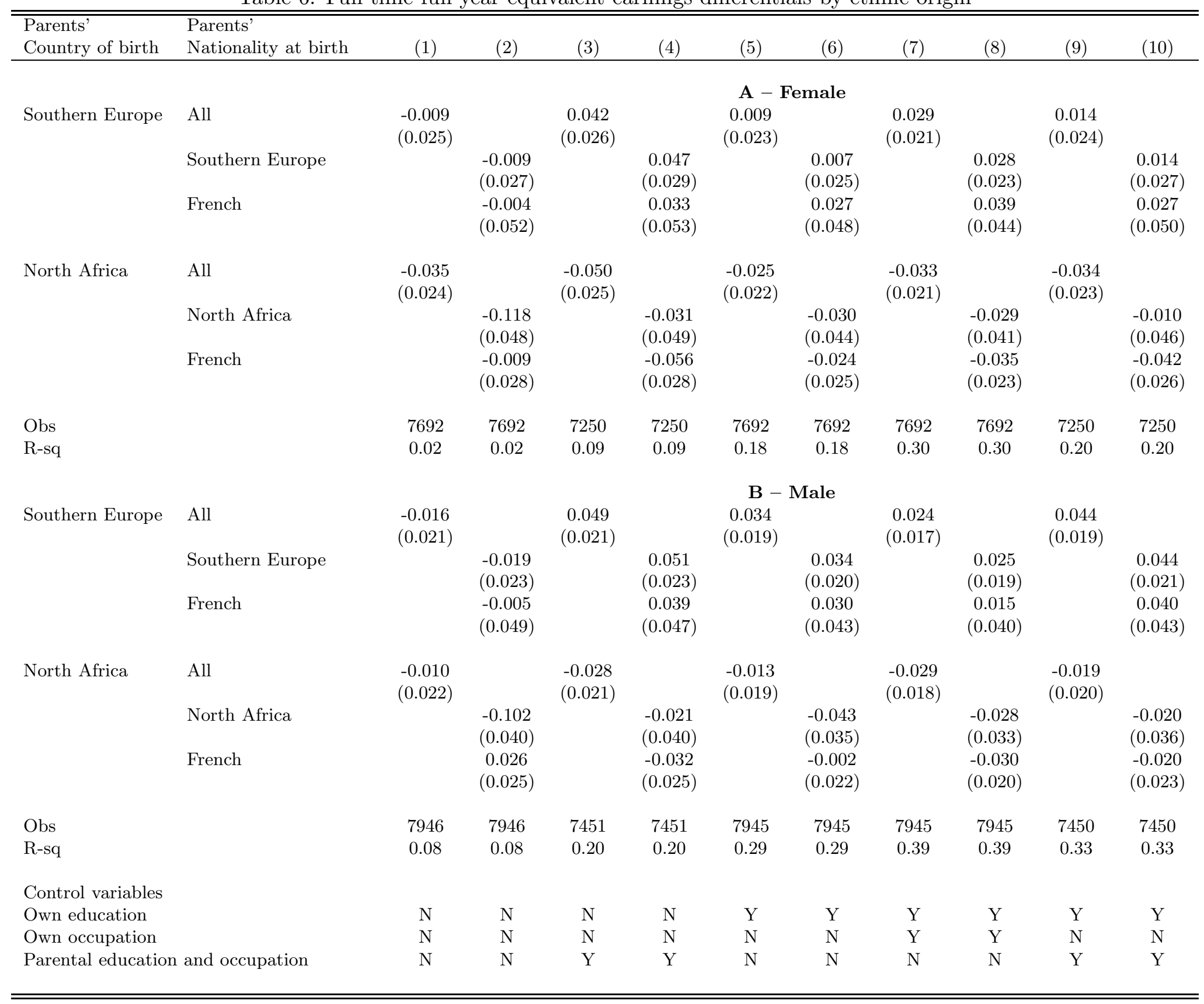


The results also suggest that great attention should be paid to precisely identifying the boundaries of the relevant ethnic groups when assessing ethnic penalties. As shown in this paper, confusing second-generation immigrants with the children of repatriated colonists induces large biases. These biases arise from the large proportion of individuals from the latter groups among the individuals whose parents where born in North Africa. They lead to underestimate the ethnic disadvantage of the former group by about two-thirds. Similar biases are to be expected in the case of individuals originating from other parts of Africa as well as from the Indochinese peninsula. One should however note that these biases are tightly connected to France's colonial and migration history. There are no reason to expect that taking national origin (besides geographical origin) has such a crucial impact in countries without a colonial history or that did not establish colonies of settlement.

The earnings disadvantage suffered by second-generation migrants from North Africa mostly results from their greater difficulties in access to employment. This more limited access to jobs is itself explained, in the case of male workers by a lower degree of job stability resulting in frequent (but relatively short) spells of unemployment. In the case of female, it is mostly driven by a low participation rate as well as by a low exit rate out of unemployment. On the contrary, discrimination in hourly wage rate and lower educational attainment play a limited role in shaping earnings differentials. In this respect, inequalities related to ethnic origin follow the same pattern as other forms of inequalities on the French labor market, where inequalities are largely conditioned by access to jobs, more than by earnings differentials.

The results of this paper also help clarify the driving determinants of observed ethnic disadvantage. About one half of the overall earnings gap experienced by second-generation migrants from North Africa is explained by their less privileged social origin. Restricting the comparison to natives with similar social origin (as defined by detailed parental occupation and education) the ethnic gap in annual earnings falls by about 10 percentage points. Once social origin is taken into consideration, taking individual human capital as an additional explanatory variable has a very modest impact on the measured earnings gap.

Taking all available individual characteristics still leaves a sizeable residual earnings gap of about $10 \%$. Assuming that we have properly controlled for both human and social capital, this residual gap should be interpreted as the extent of ethnic discrimination on the labor market. Of course, one limitation to this interpretation is the quality of our measurement of individual characteristics. As already discussed, if there remains unobserved heterogeneity related to ethnic origin, unexplained earnings differential will produce a biased estimate of the extent of discrimination. Note also that the bias could go in either direction. In this paper, I have used a fairly detailed description of individual human capital and family origin. However, it may still be the case that, for instance, a given social origin, as measured by standard occupational classifications, provide access to different types or amounts of social capital, depending on ethnic origin. In this case, the interpretation of the residual ethnic disadvantage as reflecting ethnic discrimination would not be valid. This limitation should be kept in mind when interpreting our result. But the difficulty of finding a consistent measure of social and human capital across different ethnic groups should also be emphasized.

Another aspect of the results of the previous sectoin also suggests that the ethnic disadvantage suffered by second-generation migrants from North-Africa is to some extent discriminatory. A popular story to account for the lower socio-economic achievement of children of migrants underlines the cost of migration for the parents and the fact that these parents typically hold low-status positions in the destination country. In fact, second-generation migrants from Southern Europe and North Africa share this situation 
in common : in both case, taking parental background into consideration significantly reduces the gap between migrants and natives. One crucial difference is, however, that once parental background and individual human capital is taken into account, second-generation migrants from Southern Europe experience a net ethnic advantage. As is sometimes suggested, this ethnic advantage may reflect the benefits associated to the existence of ethnic solidarities and ethnic niches in particular industries. But one should also emphasize that the gap between ethnic groups, once social origin and individual education are controlled for is particularly large (around 20 percentage points). It is, in fact, likely to be too large to be solely explained by ethnic niches. Which, in turn suggests that this large gap reflects to some degree a specific ethnic discrimination against individuals with North African origin. This interpretation is consistent with evidence obtained in other contexts, such as audit tests (Cediey and Foroni, 2006) but requires further empirical work using a better characterization of individual human and social capital.

\section{References}

Aeberhardt, R. and Pouget, J. (2006). National origin wage differentials in France, mimeo CREST-INSEE .

Alba, R. and Silberman, R. (2002). Decolonization Immigrations and the Social Origins of the Second Generation: The Case of North Africans in France, International Migration Review 36(4): 1169-1193.

Altonji, J. G. and Blank, R. M. (1999). Race and gender in the labor market, in O. Ashenfelter and D. Card (eds), Handbook of Labor Economics, Vol. 3C, North-Holland, Amsterdam, chapter 48, pp. 3143-3259.

Arneson, R. (1989). Equality and equal opportunity of welfare, Philosophical Studies 56: $77-93$.

Arneson, R. J. (1999). Against Rawlsian equality of opportunity, Philosophical Studies 93(1): $77-112$.

Arrow, K. (1972). Models of job discrimination, in A. Pascal (ed.), Racial Discrimination in Economic Life, D.C. Heath, Lexington, Mass., pp. 83-102.

Black, D. A. (1995). Discrimination in an equilibrium search model, Journal of Labor Economics 13(2): 309-334.

Boumahdi, R. and Giret, J.-F. (2005). Une analyse économétrique des disparités d'accès à l'emploi et de remunérations entre jeunes d'origine française et jeunes issus de l'immigration, Revue économique 56(3): 625-636.

Breen, R. (ed.) (2004). Social Mobility in Europe, Oxford, New York.

Brinbaum, Y. and Werquin, P. (2004). Des parcours semés d'embûche : l'insertion professionnelle des jeunes d'origine maghrébine en france, in L. Achy, J. De Henau, N. El Kadiri, K. Kateb, J. Laufer, C. Marry, M. Maruani, D. Meulders, R. Silvera, C. Sofer and S. Zouari (eds), Marché du travail et genre, Maghreb-Europe, édition Dulbea, Brussels.

Canaméro, C., Canceill, G. and Cloarec, N. (2000). Chômeurs étrangers et chômeurs d'orginie étrangère, DARES Premières Synthèses (46.2). 
Cediey, E. and Foroni, F. (2006). Les discriminations à raison de "l'origine" dans les embauches en France une enquête nationale par tests de discrimination selon la méthode du BIT, Technical report, Bureau international du Travail, Genève.

Cohen, G. A. (1989). On the currency of egalitarian justice, Ethics 99: 906-944.

Corten, R. and Dronkers, J. (2004). School achievement of pupils from the lower strata in public, private government-dependent and private government-independent schools: a cross-national test of the Coleman-Hoffer thesis., EUI working paper (SPS 2004/12).

EUMC (2004). Migrants, Minorities and Education, Office for Official publicatoins of the European Communities.

Fleischmann, F. and Dronkers, J. (2007). The effects of social and labour market policies of eu-countries on the socio-economic integration of first and second generation immigrants from different countries of origin., Technical report, European University Institute.

Granovetter, M. (1974). Getting a Job : A Study of Contacts and Carreers, Harvard University Press, Cambridge.

Heath, A. and Cheung, S. (forthcoming). Unequal chances : Ethnic minorities in Western labor markets, Oxford University Press, Oxford.

Héran, F. (2002). Les immigrés et leurs descendants dans le système statistique français : quelque réflexions sur les pratiques et les principes, Immigration, marché du travail, intégration, Commissariat genéral du plan, Paris, pp. 121-134.

Lefranc, A., Pistolesi, N. and Trannoy, A. (2006). Equality of opportunity: Definitions and testable conditions, with an application to income in france (1979-2000), RSCAS working paper 35, European University Institute.

Lefranc, A., Pistolesi, N. and Trannoy, A. (2008). Inequality of opportunities vs. inequality of outcomes: Are western societies all alike ?, Review of Income and Wealth pp. 513543.

Meurs, D., Pailhé, A. and Simon, P. (2006). Mobilité entre générations d'immigration et persistance des inégalités : l'accès à l'emploi des immigrés et de leurs descendants en France, Population (5/6): 763-801.

Meurs, D. and Ponthieux, S. (2000). Une mesure de la discrimination dans l'écart de salaires en hommes et femmes, Economie et Statistique (337-33).

Mortensen, D. T. (1986). Job Search and Labor Market Analysis, in O. Ashenfelter and R. Layard (eds), Handbook of Labor Economics, Vol. 2, North-Holland, Amsterdam, chapter 15, pp. 849-919.

Neal, D. A. and Johnson, W. R. (1996). The role of premarket factors in black-white wage differences, The Journal of Political Economy 104(5): 869-895.

OECD (2006). Where Immigrant Students Succeed: A Comparative Review of Performance and Engagement in PISA 2003, Vol. 8 of Education 83 Skills, OECD, Paris.

Phalet, K. and Heath, A. (2007). From ethnic boundaries to ethnic penalties : Urban economies and the Turkish second generation, Technical report, University of Utrecht. 
Rawls, J. (1971). A theory of justice, Harvard University Press, Cambridge, MA.

Roemer, J. (1993). A pragmatic theory of responsibility for the egalitarian planner, Philosophy and Public Affairs 22(2): 146-166.

Roemer, J. (1998). Equality of Opportunity, Harvard University Press, Cambridge.

Shavit, Y. and Blossfeld, H.-P. (eds) (1993). Persistent inequality : changing educational attainment in thirteen countries, Westview Press, Boulder, Colorado.

Silberman, R., Alba, R. and Fournier, I. (2007). Segmented assimilation in france? discrimination in the labour market against the second generation, Ethnic and Racial Studies 30(1): 1-27.

Silberman, R. and Fournier, I. (forthcoming). Is French society truly assimilative ? immigrant parents and offspring on the Frenc labor market, in A. Heath and S. Cheung (eds), Unequal Chances: Ethnic minorities in Western Labour markets, Oxford University Press.

Simon, P. and Clément, M. (2006). Comment décrire la diversité des origines en France ? une enquête exploratoire sur les perceptions des salariés et des étudiants, Population et sociétés (INED) (425).

Solon, G. (1999). Intergenerational mobility in the labor market, in D. Card and O. Ashenfelter (eds), Handbook of Labor Economics, Vol. 3B, North-Holland, Amsterdam, chapter 29, pp. 1761-1800.

Tribalat, M. (1996). L'enquête mobilité géographique et insertion sociale : remise en cause des habitudes statistiques françaises", Espace, Populatios, Sociétés (2-3): 215-225.

Veenman, J. (2007). Measuring labour market discrimination : An overview of methods and their characteristics, Technical report, ERCOMER, University of Utrecht. 